\title{
GENE-POSTULATION FOR STEM RUST RESISTANCE IN TWENTY CERTAIN EGYPTIAN WHEAT VARIETIES \\ Shahin, A. A. ${ }^{*}$; A. A. Abu Aly ${ }^{1}$; I. A. Youssef ${ }^{1}$ and A.O. El-Shimy ${ }^{2}$ \\ 1 Plant Disease Res. Dept., Sakha Agric. Res. Station, Institute of Plant Pathology, ARC, Egypt \\ ${ }^{2}$ Plant Pathology Research Institute, Agric. Res. Center, Giza, Egypt
}

\begin{abstract}
Matching of sixteen monogenic lines and twenty wheat (Triticum aestivum L.) varieties representing the Egyptian germplasm inoculated with thirty different stem rust isolates to postulate stem rust resistance gene $(S r)$. Genes were determined according to the infection types (IT) to different Puccinia graminis f. sp. tritici isolates for seedling resistance in wheat varieties. All of the tested varieties were probably present in Sr7b and Sr8a, with the exception of Giza 160 and Sohag-3, whereas, Sr9e gene were detected in Gemmeiza-7 but it was not detected in the rest of tested varieties. Thirteen genes were probably present in Gemmeiza-7 (the highest), however Sakha 61, Sohag-3 and Sakha 160 wee included the least genes (Sr's). Sr29, Sr30, Sr36 followed by Sr7b and Sr8a were most commonly postulated and having the highest frequency, while $\mathrm{Sr} 9 e, \mathrm{Sr} 21$, Sr26 $\mathrm{SrT}_{t-1}$ appeared in lower frequencies within the used Egyptian wheat varieties.

Keywords: stem rust, Sr's genes, postulation, infection type.
\end{abstract}

\section{INTRODUCTION}

Wheat stem rust caused by Puccinia graminis f. sp. tritici Eriks \& Henn. Play an important role in wheat production in Egypt with rust diseases of wheat (Triticum aestivum L.). Stem rust can attack all of the above ground parts of the plant, damage to plants results from the loss of photosynthetic area. Severe losses have been Roelfs (1978) and Statler, (1971). Gene(s) conditioning resistance to Pgt. in these varieties are largely unknown. Therefore previously studies reported that Sr9g, Sr9b,Sr25 and Sr36 were common and having the highest frequency, while, Sr5, Sr9e, Sr24, Sr26, Sr29 and SrGt+ were not detected and may be absent in the some Egyptian wheat varieties Imbaby et al., (1997). Genes conditioning resistance to stem rust in Egypt and Neighbouring countries seem to be Sr9e, Sr22, Sr24, Sr26 and Sr27, since they were effectively resistant to most isolated virulences Abd El-Hak et al., (1982). Resistance in this wheat to Australian pathotypes was determined by combination of known and unknown genes more recently, Singh and Mclntosh (1986) reported that Kenya plume possessed eight genes Sr2, Sr5, Sr6, Sr7a, Sr8a, Sr9b, Sr12 and Sr17. Shahin (2002) indicated that resistance genes i.e. Sr36, Sr30, Sr29 followed by Sr7b, Sr8a were present in 20 Egyptian cultivars, however $S r T_{t-1}, S r 26, S r 21, S r 9 e$ were

Correspondence author:

Present address: Plant Diseases Dept., Sakha Agric. Res. Center, Kafer El-Sheikh, Egypt

E-mail: a.a.shahin@hotmail.com 
Shahin, A. A. et al.

less frequent, in another term the local cultivars lacked these genes to be incorporated.

The main objectives of present investigation had been to study was conducted to determine probable gene $(\mathrm{Sr})$ resistance in twenty Egyptian wheat varieties share genes for resistance to Pgt.

\section{MATERIAL AND METHODS}

Twenty wheat varieties representing the Egyptian germplasm indicated in Table (1) in addition to known stem rust resistance genes i.e. Sr's Table (2) were tested for stem rust resistance using 30 cultures of stem rust Puccinia graminis tritici obtained from collected samples of 2005/2006. The materials were tested obtained from Cereal Dis. Res. Dept., Plant Pathology Research Institute., Agricultural Research Center, Giza, Egypt.

These varieties were grown in the greenhouse at Giza Agric. Res. Stn., during 2007/2008. Rust data were recorded as infection types according to the method of Stakman et al. (1962). All wheat materials were grown in plastic pots, with $10 \mathrm{~cm}$. diam. each pot contained four varieties in each corner clockwise.

Table (1). List of Egyptian wheat entries and their pedigree which were evaluated through out the present study.

\begin{tabular}{|l|l|c|}
\hline No. & Vars. & Pedigree \\
\hline 1 & Sids-1 & HD2172/Pavon "S"//1158.57/Maya74"S". \\
\hline 2 & Sids-6 & Maya "S"/Mon "S"//CMH74A.592/3/Sakha8*2SD/10002. \\
\hline 3 & Sids-7 & Maya "S"/Man "S"//CMH74A592/3/Sakha8*2SD/10002 \\
\hline 4 & Sids-8 & Maya "S" /Man “S"//CMH74A592/3/Sakha8*2S D/10002. \\
\hline 5 & Sids-9 & Maya“S"/Man“S"/4/CMH72.428/MRC//JUP/3/CMH74A582/5/Gi \\
za 157*2SD10003.
\end{tabular}


Inoculation and incubation were performed in moist chambers at 20$24^{\circ} \mathrm{C}$. Inoculated plants were held at approximately $100 \%$ relative humidity for 24 hr., plants were returned to the greenhouse bench at $22-24^{\circ} \mathrm{C}$ till disease on set. Rust reaction on the first leaf was recorded (22 days after sowing) following the method adopted by Stakman, et al. (1962).

The infection type on each cultivar or near isogenic line was classified at the scale of $(0-4) .12$ days after inoculation, where infection types (IT) i.e. $\mathrm{R}=(0,0 ;, 1$ and 2$)$ were classified as low infection type (LIT) or resistant and $S=(3$ and 4$)$ were considered as high infection types $(\mathrm{HIT})$, or susceptible using a method similar to those of Browder, (1973) and Statler (1984) to determine the probable resistance genotypes of the cultivars for each pair of tested hosts.

Table (2). Cultivars and lines of wheat carrying single genes for resistance used to identify stem rust cultures in Canada. (Green 1981).

\begin{tabular}{|c|c|c|c|}
\hline \multirow[t]{2}{*}{$\begin{array}{l}\text { Genes for } \\
\text { resistance }\end{array}$} & \multicolumn{2}{|c|}{$\begin{array}{l}\text { Typical resistant } \\
\text { infection type }\end{array}$} & \multirow[t]{2}{*}{ Cultivar or line } \\
\hline & Seedling a & Adult b & \\
\hline Sr5 & 0 & I & Prelude*6/Reliance \\
\hline Sr6 & $0 ;, X$ & $\mathrm{R}$ & Mida-McMurachy-Echange/6*Perlude \\
\hline$S r 7 b$ & $2+-$ & MS & Chinese Spring/Hope (C.I. 14165) \\
\hline Sr8a & $2+-$ & MS & Chinese Spring/Red Egyptian (C.I. 14165) \\
\hline $\mathrm{Srgb}$ & $2,2,3$ & MR & Prelude*4// Marquis*6/Kenya 117A \\
\hline Sr9d & ;2- & MR & H-44-24/6*Marquis \\
\hline Sr9e & $;, ; 1+, 2$ & $\mathrm{R}$ & Vernstein W3196 \\
\hline Sr9g & $2-$ & MR & Lee \\
\hline Sr11 & $1+, ; 2$ & R-MR & Chinese Spring/Timstein C.I.14171 \\
\hline Sr17 & $0 ; 1$ & $\mathrm{R}$ & Prelude/8*Marquis*2//Esp 518/9 \\
\hline Sr21 & 0 & $\mathrm{R}$ & Tricticum monococcum \\
\hline Sr25 & 2 & MS-S & Agropyron elongatum \\
\hline Sr26 & ;2- & MR & Agropyron elongatum \\
\hline Sr27 & 0 ; & I & WRT 238-5 \\
\hline Sr29 & $2-$ & MS & Prelude/8*Marquis//Etoil de Choisy \\
\hline Sr30 & 2 & MS & Webster \\
\hline Sr36 & $0 ; \mathrm{X}$ & $\mathrm{I}, \operatorname{Tr} \mathrm{S}$ & Prelude*4/NHLII.64.62.1 \\
\hline SrGt+ & $2+$ & MS & Gamut \\
\hline$S r T_{t-1}$ & 2 & $\mathrm{R}$ & W269LSrT ${ }_{\mathrm{t}-1}$ \\
\hline
\end{tabular}

${ }^{a}$ Low infection types at $18^{\circ} \mathrm{C}$, may vary at other temperature.

' I = immune, $R$ = resistant, MR = moderately resistant, MS = moderately susceptible, S = susceptible, $\operatorname{Tr} \mathrm{S}=$ trace susceptible.

${ }^{c}$ Cited after Green (1981).

Matching or comparing the cultivars with unknown resistance genes (host $B$ ) to the isogenic lines each carrying single known gene for resistance to stem rest (host A) was performed. The infection types of tested cultivars were classified into four categories according to the following scheme.

Host A

Host B

Resistant

Resistant

LIT:LIT

Susceptible

HIT:LIT

Susceptible

LIT:HIT

HIT:HIT 
The HIT:LIT and LIT:HIT infection types are most critical to determine probable resistance genotypes. The four categories were based on whether or not each of these infection types occurred.

Category 0: absence of LIT:LIT isolates indicating that host B has the same gene(s) as in host A, however host B may have additional resistance genes.

Category -: no of HIT:LIT isolates but some LIT:HIT isolates indicating that host $B$ does not contain the resistance genes in host $A$.

Category -0: no of HIT:LIT isolates and no LIT:HIT isolates indicating that both hosts carry the same resistance genes at least for resistance to the isolates used.

Category +: some HIT:LIT isolates and no LIT:HIT isolates indicating that both hosts do not carry the same resistance gene (s).

The infection types (IT) of the twenty wheat varieties with unknown resistance genes (host $\mathrm{B}$ ) were compared to the infection types of the sixteen monogenic lines each carrying a single, known gene for deduce $\mathrm{Sr}$ genes account for the resistance to stem rust (host $A$ ).

\section{RESULTS}

Data presented in Table (3) revealed the matching of 16 monogenic lines and 20 commercial wheat varieties against 30 isolates of stem rust pathogen $(P$. graminis triticl). These data indicated the presence of low infection type: high infection type in the (commercials : monogenic) indicating the inclusion of the $\mathrm{Sr}$ within the genetic make up of the commercial cultivar. This was assigned by the symbol (0).

Other group of comparisons showed the presence of low infection type: high infection type and high infection type: low infection types between the commercials and monogenics against the tested isolates and this would indicate that each of the vars. may have gene(s) not involved in the other. It was assigned by the symbol (+). Certain group showed low infection types within the monogenics, however the commercials exhibited high infection type in the matching against the isolates. This would indicate the absence of such gene (s) within the commercials, and would assigned by the symbol (-).

Data in Table (4) revealed the probable resistance genes may be presented in the genetic back ground of certain commercial varieties as derived from the last table. These data indicated that cultivar Sakha 61 included the least number of stem rust resistant genes i.e. (3) followed by Giza 160 (4). On the other hand, Gemmeiza-7 exhibited the highest number of genes i.e. 13 followed by Giza 167 (11) and Giza 165, Sohag-1 (10). The rest of cultivars included between 5 and 9 resistant genes.

As regard to the distribution of stem rust resistant genes within commercial cultivars, data presented in Table (5) revealed that $\mathrm{Sr} 36$ is the most common gene within the Egyptian commercials, i.e. (20 var.) followed by Sr29 and Sr30 (95\%), Sr8a (80\%) and Sr7b (80\%). The rest of resistance genes ranged between $5 \%$ and $30 \%$. 
Table (3). Incidence of low infection type : high infection type (R:S) comparisons of monogenic lines and varieties inoculated with $\mathbf{3 0}$ isolates of Puccini graminis f. sp. tritici.

\begin{tabular}{|c|c|c|c|c|c|c|c|c|c|c|c|c|c|c|c|c|}
\hline \multirow{2}{*}{ Variety (A) } & \multicolumn{16}{|c|}{ Host monogenic lines Sr's (B) } \\
\hline & Sr5 & Sr6 & Sr7b & Sr8 & Sr9 & Sr9 & Sr11 & Sr17 & Sr21 & Sr2 & Sr27 & Sr2S & Sr3C & Sr36 & SrG & $S r T_{t-1}$ \\
\hline Sids-1 & + & + & + & + & + & + & + & + & + & - & 0 & 0 & 0 & 0 & + & + \\
\hline Sids-6 & + & + & 0 & 0 & + & + & + & + & + & + & + & 0 & 0 & 0 & + & + \\
\hline Sids-7 & 0 & 0 & 0 & 0 & + & + & + & + & + & + & + & 0 & 0 & 0 & + & + \\
\hline Sids-8 & + & + & 0 & 0 & + & + & + & + & + & + & + & 0 & 0 & 0 & + & + \\
\hline Sids-9 & + & + & 0 & 0 & + & + & + & + & + & - & + & 0 & 0 & 0 & + & + \\
\hline Giza 160 & + & + & + & + & + & + & + & + & + & + & + & 0 & 0 & 0 & + & + \\
\hline Giza 164 & + & 0 & 0 & 0 & + & + & + & + & + & + & + & 0 & 0 & 0 & + & + \\
\hline Giza 165 & 0 & + & 0 & 0 & + & 0 & 0 & + & 0 & + & 0 & 0 & 0 & 0 & + & + \\
\hline Giza 167 & 0 & 0 & 0 & 0 & + & 0 & + & 0 & + & + & 0 & 0 & 0 & 0 & 0 & + \\
\hline Giza 168 & + & 0 & 0 & 0 & + & + & + & + & + & - & + & 0 & 0 & 0 & + & + \\
\hline Sakha 8 & + & + & 0 & 0 & + & + & + & + & - & - & + & 0 & 0 & 0 & + & + \\
\hline Sakha 61 & + & + & + & 0 & + & + & + & + & + & + & + & + & + & 0 & 0 & + \\
\hline Sakha 69 & + & + & 0 & 0 & + & + & + & + & + & + & + & 0 & 0 & 0 & + & + \\
\hline Sakha 202 & + & + & 0 & 0 & + & + & + & + & + & + & + & 0 & 0 & 0 & 0 & + \\
\hline Gemmeiza-3 & + & + & 0 & 0 & + & + & + & + & + & + & + & 0 & 0 & 0 & 0 & + \\
\hline Gemmiza-5 & + & + & 0 & 0 & + & + & + & + & + & + & + & 0 & 0 & 0 & + & + \\
\hline Gemmeiza-7 & 0 & + & 0 & 0 & + & 0 & + & 0 & + & + & 0 & 0 & 0 & 0 & 0 & + \\
\hline Sohag-1 & 0 & + & 0 & 0 & + & 0 & + & 0 & + & + & 0 & 0 & 0 & 0 & 0 & + \\
\hline Sohag-3 & + & + & + & + & + & + & + & + & + & + & + & 0 & 0 & 0 & + & + \\
\hline \begin{tabular}{|l} 
Bani \\
Sweif-1
\end{tabular} & + & + & 0 & 0 & + & + & + & + & + & - & + & 0 & 0 & 0 & + & + \\
\hline
\end{tabular}

Table (4). Probable resistance genes for stem rust in some Egyptian wheat entries.

\begin{tabular}{|l|l|c|}
\hline No. & Wheat entries & Probable Sr genes \\
\hline 1 & Gemmeiza-3 & $7 b, 8 a, 29,30,36, \mathrm{Gt}^{+}$ \\
\hline 2 & Gemmeiza-7 & $5,6,7 b, 8 a, 9 e, 9 g, 11,26,29,30,36, \mathrm{Gt}^{+}, \mathrm{T}_{t-1}$ \\
\hline 3 & Gemmeiza-5 & $27,29,39,30,36$ \\
\hline 4 & Giza 160 & $6,7 b, 8 a, 29,30,36$ \\
\hline 5 & Giza 164 & $5,7 b, 8 a, 9,11,21,27,29,30,36$ \\
\hline 6 & Giza 165 & $5,6,7 b, 8 a, 9 g, 17,27,29,30,36, \mathrm{Gt}^{+}$ \\
\hline 7 & Giza 167 & $6,7 b, 8 a, 29,30,36$ \\
\hline 8 & Giza 168 & $7 b, 8 a, 29,30,36, \mathrm{G} t^{+}$ \\
\hline 9 & Sakha 202 & $8 a, 36, \mathrm{G}+$ \\
\hline 10 & Sakha 61 & $7 b, 8 a, 29,30,36$ \\
\hline 11 & Sakha 69 & $7 b, 8 a, 29,30,36$ \\
\hline 12 & Sakha 8 & $27,29,30,36$ \\
\hline 13 & Sids-1 & $7 b, 8 a, 29,30,36$ \\
\hline 14 & Sids-6 & $5,6,7,8 a, 29,30,36$ \\
\hline 15 & Sids-7 & $7 b, 8 a, 29,30,36$ \\
\hline 16 & Sids-8 & $7 b, 8 a, 29,30,36$ \\
\hline 17 & Sids-9 & $7 b, 8 a, 29,30,36$ \\
\hline 18 & Beni Sweif-1 & $29,30,36$ \\
\hline 19 & Sohag-1 & $5,7 b, 8 a, 9 g, 17,27,29,30,36, \mathrm{Gt}^{+}$ \\
\hline 20 & Sohag-3 & \\
\hline
\end{tabular}


Table (5). Probable resistance genes for stem rust in some Egyptian wheat entries.

\begin{tabular}{|c|c|c|c|}
\hline No. & Srgenes & Frequency & $\%$ \\
\hline 1 & Sr5 & 5 & 25 \\
\hline 2 & Sr6 & 5 & 25 \\
\hline 3 & $S r 7 b$ & 16 & 80 \\
\hline 4 & Sr8a & 16 & 80 \\
\hline 5 & Sr9e & 1 & 5 \\
\hline 6 & Sr9 & 4 & 20 \\
\hline 7 & Sr11 & 2 & 10 \\
\hline 8 & Sr17 & 2 & 10 \\
\hline 9 & Sr21 & 1 & 5 \\
\hline 10 & Sr26 & 1 & 5 \\
\hline 11 & Sr27 & 4 & 20 \\
\hline 12 & Sr29 & 19 & 95 \\
\hline 13 & $\mathrm{Sr} 30$ & 19 & 95 \\
\hline 14 & Sr36 & 20 & 100 \\
\hline 15 & $\mathrm{SrGt}+$ & 6 & 30 \\
\hline 16 & $S r T_{t-1}$ & 1 & 5 \\
\hline
\end{tabular}

\section{DISCUSSION}

In relation to the matching test performed between Sr's and commercials versus 30 isolates of $P$. graminis tritici at seedling stage, the obtained results indicated that the commercial varieties varied in their inclusion of postulated resistant genes. For example, Sakha 61 include 3 genes (the least), however, Gemmeiza-7 included 13 genes (the highest). On the other hand, the results gave evidence to the presence of Sr's: 36, 30, 29 followed by $7 b$ and $8 a$, as the more frequent and commonest genes. However, Sr's: Tt-1, 26, 21, 9e appeared in lower frequencies within the commercials.

If we put these results in comparison with the above mentioned ones, we would find that the common genes within cultivars are lacked as effective ones. However, those effective are less frequent or less common herein. This explanation seemed to be comprehensive and logical, because the basis of the first test i.e. virulence formulae depend upon the spore samples which were collected from the susceptible cultivars. However, the basis of the matching test "gene postulation" depends upon the matching of Sr's (known gene cultivars) and the commercials (unknown gene cultivars) versus high number of isolates.

This results seemed to be logical since the local commercials require Sr's: Tt-1, 26, 21 and 9e which are in turn effective in the virulence analysis results were reported by Claude et al. (1986); Hu and Roelfs (1986); Singh and McIntosh (1986); Hu (1988) and Imbaby et al., (1997); Shahin, A.A. (2002).

\section{REFERENCES}

Abd El-Hak, T.A.; N. El-Sherif; I. Shafik; A.A. Bassioni; S. Keddis and Y.H. ElDaoudi (1982). Studies on wheat stem rust virulence and resistance genes in Egypt and neighboring countries, Egypt. J. Phytopath. 14, No. 1-2, pp. 1-10.

Browder, L.E. (1973). Probable genotype of some Triticum aestivum. Agent derivative for reaction to Puccinia recondite f. sp. tritici. Crop Sci. 13:203-206. 
Claude, P.P.; P.L. Dyck and L.E. Evans (1986). An evaluation of 391 spring wheat introduction for resistance to stem rust and LEAF RUST. Can. J. Plant Path. 8:132-139.

Green, G.J. (1981). Identification of physiologic races of Puccinia graminis $f$. sp. tritici in Canada. Can. J. Plant Pathol. 3:33-39.

$\mathrm{Hu}$, C.C. (1988). Postulation of genes for stem rust resistance in 36 Chinese wheat cultivars. Scientia Agricultura Sinica. 21(5):45-52.

$\mathrm{Hu}$, C.C. and A.P. Roelfs (1986). Postulation of genes for stem rust resistance in 24 Chinese wheat cultivars. Cereal Rusts. Bulletin, 14(2): 61-67.

Imbaby, I.A.; Y.H. El-Daoudi; M.A. Mostafa; M.M. El-Shhamy and A.M.M. Saleh (1997). Probable genes for stem rust resistance in ten new Egyptian wheat varieties Assiut Journal of Agricultural Sciences 28(2):107-115.

Roelfs A.P. (1978). Estimated losses caused by rust in small grain cereals in the United States-1918-76. USDA. Misc. Pub. 1363. U.S. Government Printing Office, Washington. DC.

Shahin, A.A. (2002). Studies on stem rust disease of wheat. M. Sc. Thesis, Fac. Agric. Tanta Univ. 127pp.

Singh, R.P. and R.A. Mclntosh (1986). Genetic of resistance to Puccinia graminis tritici and Puccinia recondita tritici in Kenya wheat. Euphytica 35: 245-256.

Stakman, E.C.; D.M. Stewart and W.Q. Loegering (1962). Identification of physiologic races of Puccinia graminis var. tritici A.R.S. USDA Agric. Res. Serv. Bull. E. 617-53 pp.

Statler, G.D. (1971). The virulence and potential destructiveness of wheat leaf rust in North Dakota. N.D. Farm Res. 29:7-10.

Statler, G.D. (1984). Probable genes for leaf rust resistance in several hard red spring wheats Crop Sci. 24: 883-886.

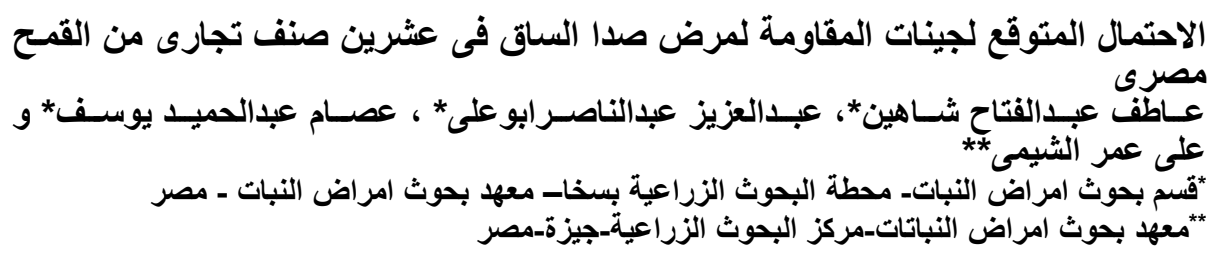

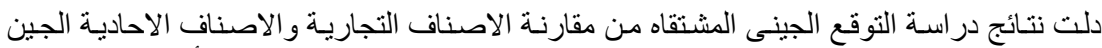

Monogenic lines (Sr's)

ذلك للتعرف على العو امل الور اثية (جينات المقاومة) المتوقع وجودها فى طور البادرة فى بعض اصنى اصناف القـح

$$
\text { التجكن تلخيص فى مصر أهم النتائتج فى الاتحى: }
$$

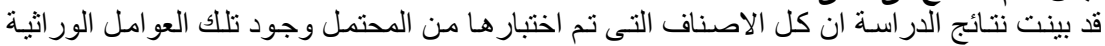

Sr7b and Sr8a

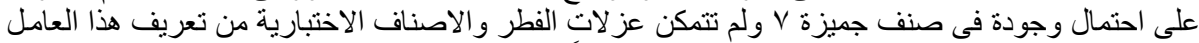

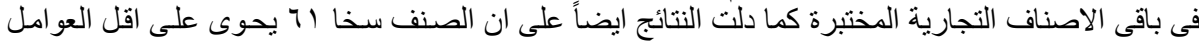

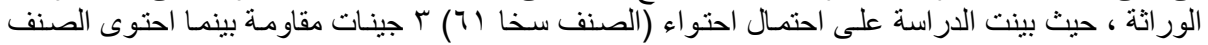

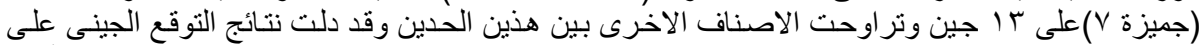

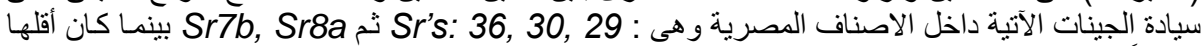

شيو عاً داخل الاصناف SrTt-1, Sr26, Sr21, Sr9e 